\title{
EXAMINATION OF WORKER-LOCATION MEASUREMENT METHODS AS A RESEARCH TOOL FOR AUTOMATED LABOR CONTROL
}

\author{
Ronie Navon ${ }^{1}$, Eytan Goldschmidt ${ }^{2}$ \\ ${ }^{1}$ Department of Structural Engineering, Faculty of Engineering Sciences, Ben-Gurion University \\ of the Negev, Israel. On leave from the Faculty of Civil and Environmental Engineering, \\ Technion - Israel Institute of Technology, Haifa 32000, Israel \\ ${ }^{2}$ Faculty of Engineering, Department of Civil Engineering, Ariel University Center of Samaria, Israel

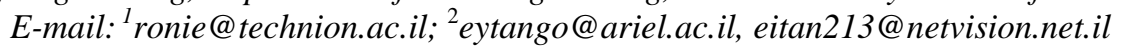

Received 23 Mar. 2009; accepted 24 Jan. 2010

\begin{abstract}
Automatic labor performance measurement is a challenging area of research. Little work has been done in this area due to its complexity and the absence of adequate research tools. The authors used the approach of indirect parameters to automate the performance measurement. In this approach, the location of the worker is measured as a function of time and special algorithms convert these data into labor inputs, or productivity. Research in this area requires a reliable method, or tool, for workers location measurement - such a tool does not exist. Three methods of location measurement are examined in this paper as research tools for automated labor control: (1) manual simulation of location measurement, (2) GPS, and (3) video photography. The first two methods were found to be subjective, inaccurate and unreliable. The third was found to be suitable for the purpose of the present research. This method uses a classical time-lapse technique, together with a video-based method developed in the present research.
\end{abstract}

Keywords: automation; control methods; data collection; research tools.

\section{Introduction}

Despite the use of computerized systems, companies often spend days or weeks collecting, compiling, and analyzing data (Chul and Liang 2008). Thus, many opportunities to optimize resources are missed due to the lack of real-time, up-to-date information. Labor, in particular, is a very important resource and it is very difficult to collect real-time data relating to its on-site performance. Measuring labor performance manually is labor intensive, inaccurate and error prone. This is why it is not done on a regular basis. Some researchers assert that although using automated data collection technologies increases the chance to improve data collection, still many processes are done today manually (Jang and Skibniewski 2009).

For a number of years we have been engaged in research attempting to automate labor performance measurement (Goldschmidt and Navon 1996; Navon and Goldschmidt 2003a, 2003b; Navon et al. 2004). The research assumes that in the absence of a direct way to measure labor performance automatically, an indirect approach is needed - in this approach (described in Section 0) an indirect parameter is measured automatically and converted by special algorithms into labor performance parameters.

The first stage of this research identified a potential indirect parameter: worker location. On-site experiments were conducted to determine if this parameter can really be used for this purpose. In these experiments location measurement was simulated on site and conversion algo- rithms were used to determine what the worker was doing at any given time (part of the model of automated laborinputs measurement was developed for this purpose). Based on these data, the productivity was calculated. The results of these experiments were encouraging (Section 0) - hence three things were determined: (i) the location of a worker can help in determining what the worker is doing at the given time. (ii) These locations, and the times they were measured in, can be used by the algorithm, which determines productivity. (iii) Hence, labor productivity, or inputs, can be measured automatically.

A comprehensive survey of technologies suitable for this purpose was conducted together with a conceptual development of a data collection model (Navon and Goldschmidt 2003b). The survey showed that there is no off-the-shelf technology capable of measuring the location of construction workers in real-time on-site. The encouraging results of the simulated experiments, on the one hand, together with the unavailability of an off-theshelf measurement tool, lead to the next stage: on-site experiments with actual location measurement by GPS. As shown in Section 0, the results of this stage were poor. In the previous stage the location measurement was only simulated, hence only part of the model was verified. Moreover, the actual work conducted by the workers needed to verify the model - was determined as part of the simulated location measurement. Three possible reasons for the poor results were considered as research questions at this stage: (i) is the GPS unsuitable as a mea- 
surement tool? (ii) Does the model function properly? (iii) Is the validation method unsuitable?

In order to answer these research questions, a tool was sought, which is capable of collecting the locations of workers as function of time for the research stage. This means that the tool (i) does not have to provide the location in real-time; (ii) it does not have to be compact nor robust and (iii) it has to record the locations in such a way that will support the objective of the research, namely to check the model developed in this research.

The present paper describes the development and the experiments with three research tools: simulation of location measurement, GPS and video. The resolution of the research question and the development of the suitable research tool were needed to advance the research of automated labor control.

\section{Labor control: previous work}

Very little work has been done to automate labor performance measurement, primarily because of the complexity of the problem. There were isolated efforts to do so, but they were only partially automated. Some researchers proposed to use Radio Frequency Identification (RFID) or barcodes to collect data relating to labor (Echeverry and Beltran 1997; Jaselskis and El-Misalami 2003; Oh et al. 2004), others suggested spreadsheet or electronic forms (Fayek et al. 1998; Hegazy and Ersahin 2001). We are also working on a method that uses RFID technology for this purpose, as briefly explained in the Conclusions Section.

The British Research Establishment presented another approach to labor performance measurement (called CALIBRE), using a full time observer(s) and a hand-held computer (Winch and Carr 2001). The observer tours the site at regular time intervals and records tasks being undertaken, classifying them in four categories: (1) value adding, (2) non-value adding, (3) support time, and (4) statutory. CALIBRE is currently commercially available under the name of COMPASS-IP (COMPASS-IP 2009).

The most futuristic approach to automate labor performance measurement is based on monitoring the body position and movement of workers (COMPASS-IP 2009). These data are collected from 6-DOF (degrees of freedom) motion sensors attached to the helmet, arms and legs of the worker. The authors report that the prototype's accuracy is at least $96 \%$.

\section{Principles of automated labor performance measurement}

The rationale behind the present development is that each construction activity - a set of tasks performed by a crew to shape and place a material into its final position (Riley and Sanvido 1995) - has well defined spaces associated with it (Akinci et al. 2002). Akinci et al. (2002) classified 13 spaces in three categories: "macro-level space, microlevel space and paths”. The micro-level space is the space required within the proximity of the components being installed, occupied by crews and equipment. These spaces also include the building components to be installed. Consequently, the present research assumed that by knowing the worker's location at a given time, together with additional information (e.g. worker's trade and candidate activities for the given day), the activity s/he is working on can be determined. Therefore, the worker's location was selected as the indirect parameter (Navon and Goldschmidt 2003a).

To check this idea, a preliminary model, based on conversion algorithms, that translates the locations into labor inputs was developed (Navon and Goldschmidt 2003a). The algorithms use two sources of data: (i) a Project Model, which provides data referring to the planned inputs, the schedule and the physical design of the building; and (ii) data relating to the actual performance, as measured by an Automated Data Collection (ADC) module, which uses ADC technology to measure the location of each worker at regular time intervals.

The conversion algorithms calculate the time workers spend being involved performing each activity and associate this time with the amount of work performed by the worker, or the crew, using a work envelope (WE) concept. A WE describes a volume in space, within the proximity of the building element to be installed, in which it is assumed that a worker must be physically present in order to perform a construction activity on that element. After determining the Pending Activities (PA) the conversion algorithms determine specific WE for each PA. By associating the locations, measured by the ADC Module, to WE (each related to a different $\mathrm{PA}$ ), the conversion algorithms link the times the workers spent in a WE to an activity.

The association is done in three stages: (i) Geometrical association of each location to a building element. The result of this stage can be that the location was associated to one, or more building elements, or none at all. (ii) Association of the location to a PA, which may be comprised of one, or more, building elements. (iii) Logical association all the locations that could not be associated previously either because they were in such a location that they could be associated to more than one building element, or activity, or could not be associated to any building element, or activity - are now associated using two different sets of decision rules (DR) - these DR were based on two different logics the first is based on work continuity (WC) principles and the second is statistical (ST). Based on the location to activity association, the conversion algorithms calculate the duration of time workers spent performing each activity. After determining the completed activities, the conversion algorithms calculate the actual inputs. More detailed description of the model can be found in Navon and Goldschmidt (2003 a).

\section{Location measurement}

In order to determine the feasibility of the principles presented in the previous Section, field experiments were conducted in three building construction sites (Navon and Goldschmidt 2003a). The main purpose of these experiments was to check the research assumption that the location represents the activity that the worker performs. A positive answer would mean that automated location measurement permits automated evaluation of labor performance. Hence, at that stage the research used manual 


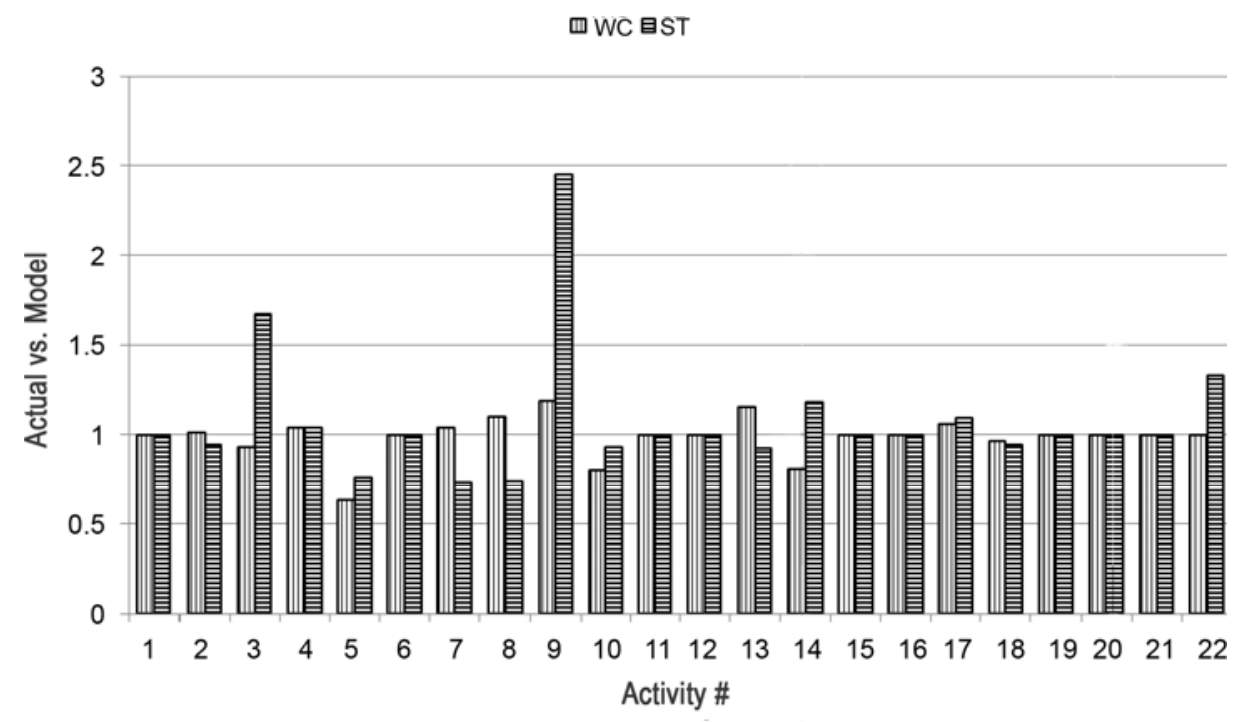

Fig. 1. Field experiment results from Tirat Hacarmel

location "measurement", or simulated location measurement (Section 0). Encouraged by the results, at the next stage, it was decided to conduct pilot tests whereby the locations would be properly measured. These tests were conducted in two construction sites using GPS as the location measurement technology - as shown in Section 0 , the results were disappointing.

In order to determine if the poor results were the consequence of the measurement technology, inadequacy of the model, or problems with the validation method, and due to the unavailability of a more suitable method for the location measurement for research purposes, the authors decided to try a different approach. Hence, two pilot tests were launched (Section 0), using video photography.

\subsection{Manual location measurement}

The initial field experiments included collection of "relative locations" (Navon and Goldschmidt 2003a) for each worker at time intervals of 10 minutes, which meant that the first two stages of the association were done manually. At the same time a researcher manually logged the actual activity the worker was engaged in during each time interval. If the worker was within a WE of a PA the researcher marked the element within whose WE the worker was at that time. If, on the other hand, the worker was within two partially overlapping WEs, or not within a WE of any PA, her/his location was marked 'two' or 'out' respectively. The relative locations were fed into the conversion algorithms, which performed the third stage of the association - the logical association. The output of the conversion algorithm was compared to the calculations of the actual work performed by the workers, based on the manual data collection.

This procedure was employed in three building construction sites: the first, in Carmiel, included three buildings with 38 apartments each. The second, in Tirat Hacarmel, included 10 buildings with six apartments each. The third in Afula, included a 10 story building with 40 apartments. The data collection took nine working days in the first site, five in the second and three in the third. The results of the first site - Carmiel - were reported in Navon and Goldschmidt (2003a). Twelve activities were monitored, in ten of them the difference between the time measured manually and that calculated by the conversion algorithms was less than $\pm 12 \%$. The difference in the other two was $\pm 23 \%$ - the reasons for which are analyzed in Navon and Goldschmidt (2003a).

Twenty two activities ${ }^{1}$ were monitored in the second site in Tirat Hacrmel (Fig. 1). The calculations of the conversion algorithms used the two sets of DR: WC (work continuity) and ST (statistical). The figure shows 22 activities on the horizontal axis and the actual vs. the conversion algorithms' calculations on the vertical axis (normalized). In most of the activities the difference between the time measured manually and that calculated by the conversion algorithm was $\pm 10 \%$ (in 18 for WC and in 15 for ST). The results from this site indicate that the WC approach is better because the ST approach yielded six deviations greater than $\pm 20 \%$ - two of them exceeding $+50 \%$.

D Activity \# 3 - formwork erection of a beam - was short and hence workers performing it were engaged in another, longer, activity. Additionally, performing this activity, the workers were outside its WE most of the time. Hence, the ST DR wrongly associated the times they spent outside Activity \# 3's WE to the other activity that they performed during this day, resulting in a large deviation. Activity \# 9 - casting - was also short and was performed by the same crew, on the same building element (and hence in the same WE) of the previous, longer, activity (\# 8 formwork erection). The ST DR mistakenly associated locations of Activity \# 9 to Activity \# 8. If the two activities were joined into one, as should have probably been done anyhow, the deviation would have been $22 \%$.

1 E.g. Rebar installation, formwork erection, internal and exterior plastering - all in various parts of different buildings. 
Due to the poorer results in the second site, the analysis of the locations measurement from the third site was done using a different strategy for the DR. This strategy involved an identification of the main worker of the crew (crew leader). Thus, at the logical association stage, all unassociated locations from the geometrical stage were associated to the activity that the conversion algorithms identified for the crew leader. Here, too, twelve activities $^{2}$ were monitored - the results were indeed better as can be seen in Fig. 2, most of the deviations between the actual to the conversion algorithms' calculation were under $\pm 10 \%$. In one activity (\# 7 - plastering) the deviation was $+21 \%$.

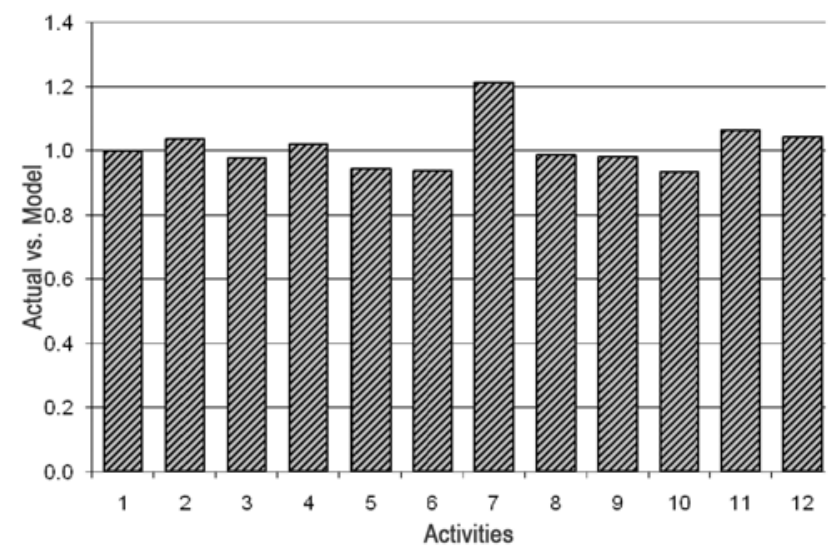

Fig. 2. Field experiment results from Afula

The conclusion from this stage was that the location of the worker does represent the activity s/he performs. These results lead to the next stage in which the worker's location was actually measured in geometrical terms.

\subsection{GPS location measurement}

The search for an off-the-shelf technology capable of recording the location of the worker in regular time intervals did not yield a suitable technology (Navon and Goldschmidt 2003b). Hence it was decided to investigate the use of GPS (Ashtech's ZX model) - a well known, widely used technology that can easily reach the accuracy required for the model. This was done in order to advance the research in spite of opinions that GPS and RFID are unsuitable for the construction environment (Jang and Skibniewski 2009) and its expected accuracies are too low for automated location measurement (Jang and Skibniewski 2009). GPS was used in earthmoving operations to continuously monitor the location of the equipment during its operation (Taylor and Tometich 2003; Peyret and Tasky 2004; Caterpillar 2009; JohnDeere 2009; Trimble 2009). In the current application, the GPS antenna was attached to the helmet (Fig. 3, taken in the second site - Section 0. The GPS antenna is marked with a circle) and the receiver was carried in a pouch attached to the worker's belt. The data collected during the experiment was downloaded to the conversion algorithms

2 E.g. Rebar installation, formwork erection, internal and floor tiling - all in various parts of the building. for analysis and compared to the actual work. The experiments were carried out in two sites, as described in the following sub-sections. The purpose of these experiments was to check the feasibility of using the GPS as a research tool to measure workers' locations at regular time intervals.

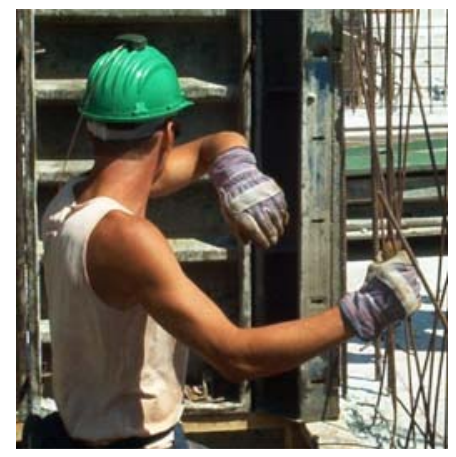

Fig. 3. Worker with GPS

\subsubsection{First site (rabin building)}

The first experiment was carried out during the construction of the new Civil and Environmental Engineering building of the Technion. The experiment took place during the erection of the frame of the eighth floor, which was constructed in a conventional method using wood formwork. The locations of one formworker were recorded at a rate of once a second for 3 hours and 18 minutes. The GPS provided locations for $71 \%$ of the time $(8,489$ readings altogether) - the rest of the time the readings of the GPS were not accurate enough (as indicated by the GPS) or there were no readings at all. In parallel, the actual work of the worker was recorded manually.

Coordinates measured by the GPS were translated from their original global reference system to a local 3D Cartesian system, whose origin was set in relation to the building layout grid. The raw data was made available as a list of location coordinates in the local 3D system, together with a time stamp for each location record. These data were then fed into the conversion algorithms. The result of this was an association of each location to a building element as shown in Table 1 - the columns represent the building elements and the rows the number of locations associated at the geometrical and the logical stages.

A total of 2,184 locations were associated at the geometrical association stage, which constitute $26 \%$ of the total measured locations. After the logical association, all 8,489 locations were associated. The actual work performed by the formworker was only on wall W-1. At the geometrical association stage only $13.1 \%$ (which is over $50 \%$ of the geometrical association) of the locations were associated correctly to $\mathrm{W}-1$ and the logical association stage brought it up to $53.3 \%$.

An analysis of the locations of the worker reveals: (a) there is a concentration of locations around wall W-1, which is the wall the worker worked on. (b) There are a number of additional concentrations of locations - these locations are where the worker performed preparatory 
Table 1. Results of the conversion algorithms

\begin{tabular}{l|c|c|c|c|c|c|c|c}
\hline & C-34 & C-41 & W-1 & W-3 & W-4 & W-5 & W-6 & Total \\
\hline Geometrical & 281 & 15 & 1,111 & 724 & 25 & 18 & 10 & 2,184 \\
\hline \% of total & $3.3 \%$ & $0.2 \%$ & $13.1 \%$ & $8.5 \%$ & $0.3 \%$ & $0.2 \%$ & $0.1 \%$ & $26 \%$ \\
\hline Logical & 1,335 & 15 & 4,523 & 2,336 & 82 & 187 & 11 & 8,489 \\
\hline$\%$ of total & $15.7 \%$ & $0.2 \%$ & $53.3 \%$ & $27.5 \%$ & $1.0 \%$ & $2.2 \%$ & $0.1 \%$ & $100 \%$ \\
\hline
\end{tabular}

work such as cutting wood planks. This second observation lead to an improvement of the WE definition - instead of being just around the building element, the WE also included designated areas of preparatory work (here determined retroactively). Adding this to the algorithms increased the rate of the correct association from $53.3 \%$ to $75 \%$.

\subsubsection{Second Site (Kiryat Yam)}

The second experiment was conducted for three days during the construction of the frame of the eighth floor in an eight story building. The frame was constructed with still formwork. The locations and the actual work of two formworkers were recorded at the same time. The workers performed work on two building elements each: The first worker (called here "Green" because of the color of his helmet) worked on the elevator shaft with steel formwork (element \# 1000) and an external wall with steel formwork (element \# 1001). The second worker (called here "Red" for the same reason) worked on an external wall with still formwork (element \# 1002) and on another external wall (element \# 1003).

The GPS provided readings for $55 \%$ of the time during the first day, 23-24\% of the time during the second day and $12-13 \%$ of the time during the third. The reason for the relatively low percent of readings in this case can possibly be attributed to the fact that the GPS antenna, which was attached to the helmet, was frequently too close to the steel formwork. This assumption is supported by the fact that each day, as the number of the steel formwork increased, the percentage of readings decreased. The low percentage of readings introduced an additional difficulty of correlating between the actual work and the measured locations. Therefore, it was decided that only the data of the first day would be analyzed because during the other two days the rate was $24 \%$ and lower, which seemed much too low.

The same procedure as the one in the first site was followed here, namely translation of the raw data to Cartesian system, which were fed to the conversion algorithms. At the beginning the algorithms used all PA, which lead to a relatively low rate of correct association. Hence, an improvement to the DR was made, which increased the rate of the correct association. The improved DR assumed that the system knows which of the PAs were actually performed during the given day. (This data can be available from a computerized daily site report (Navon and Haskaya 2007), or it could be entered manually.)

The results of the associations are shown in Fig. 4. On the horizontal axis are the four building elements; the vertical axis shows the percent of the correct association for each element broken down to the three types of association: Geometrical Association, Logical Association and the Modified Logical Association - the latter uses the improved DR. In most cases (elements \# 1000, 1001, 1002) the modified logical association meaningfully improved the results. The deviations between the actual work and the work measured with the aid of the GPS, in those elements, are 15-29\%. On the other hand, the deviation in the case of element \# 1003 is $75 \%$.

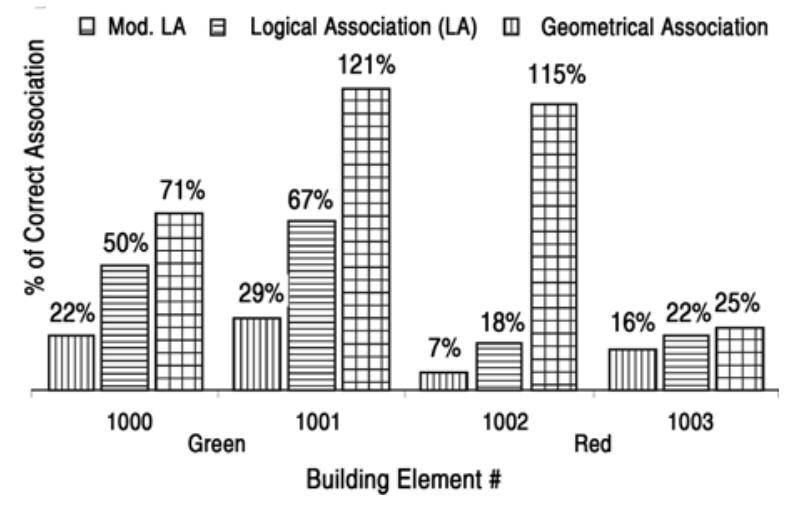

Fig. 4. Analysis results from the second site (Kityat Yam)

\subsubsection{Conclusions regarding the suitability of GPS}

The experiments with the GPS have shown that, in spite of the low accuracy required, this technology is not reliable as a research tool to measure workers location in building construction for the following reasons:

- Even in relatively open spaces, such as frame construction, the GPS does not provide readings for the entire duration of the experiment. In conventional construction, with wood formwork it gave readings for $71 \%$ of the time, and with steel formwork it gave readings for $12-55 \%$ of the time.

- It is difficult to associate between the actual work performed and the readings of the GPS, especially when there is more than one worker, or if the worker performs more than one task (in this case a task is defined as an activity performed on one building element). Hence, the analysis of the first site was easier, but the analysis of the second site was more complicated because two workers performed two tasks each. The analysis above (Section 0 ) simply reduced the figures of the actual work proportionally (e.g. the figure for the actual work that was used in the calculations was 55\% of the actual work as observed on site).

- In addition to the above, it is difficult to follow up and determine the actual work where there are two workers, or more, performing more than one task each. 
- Moreover, if the observer makes a mistake in determining the actual work, there is no way to check it, or reproduce the data. This is also a problem with the manual methods presented in Section 0 above. In other words, both manual method and the GPS, are too subjective as research tools.

- Due to the latter point, it is recommended that the actual work be determined separately from the location measurement.

In summary it can be concluded that both measurement methods - the manual and the one using GPS - are not suitable as research tools to measure workers locations in building construction. Clearly a different method should be sought.

\subsection{Video based location measurement (VBLM) tool}

For all the above reasons it was decided to try a video technology, which has been widely used for productivity improvements (Oglesby et al. 1989). The advantage of this technology is that one recording serves to determine the locations of workers as function of time as well as determining the actual work performed at the given time in a separate run. Hence this technology is objective and it permits repetition of the analysis when in doubt. This technology is not limited by the number of workers, or by the number of tasks performed by each worker during the experiment and it is available off-the-shelf. The following Sub-sections describe the location measurement methodology and two experiments. The first was conducted to check the accuracy of the methodology and the second, a pilot test.

\subsubsection{Methodology}

The methodology consists of four stages on site and in the laboratory: (a) site photography (b) digitizing - identifying and recording the locations of the workers as function of time, (c) actual work determination - running the video again and determining the actual work as function of time, (d) feeding these locations into the conversion algorithms, running them and analyzing the results.

A video camera is installed in a fixed position and the activity of the day is recorded. The recording includes a time stamp. The video is then analyzed in the laboratory in two stages - digitizing and actual work determination. The analysis is done, for each worker, according to the following steps:

1. Digitizing

1.1. Identification of the workers by their clothes, the color of the helmet, or other identifying elements. The identification of the worker is recorded in the digitizing and analysis (DA) form (Fig. 5). If another worker "appears” during the next steps, her/his identification is added.

1.2. Running the video tape at intervals of one minute according to the time stamp on the video. The time interval can principally be selected by the researcher.
1.3. For each interval, the location of the worker is identified and marked on the floor plan of the building, according to the worker's position relative to the building elements.

1.4. Identifying and measuring the worker's location based on a grid marked on the floor plan before. The $\mathrm{X}, \mathrm{Y}$ coordinates of this location and the time are entered into the DA form.

2. Actual work determination. In this step the activity the worker was engaged in, and the corresponding building element, are determined. This is done by re-running the video, for each worker separately, and determining the start and stop times of each activity for each building element. These data are entered to the DA form.

\begin{tabular}{|c|c|c|c|}
\hline \multicolumn{4}{|c|}{ Date: January 19,2006} \\
\hline Time & X I & Y & Actual \\
\hline $9: 56: 00$ & 22.00 & 15.70 & 64 \\
\hline $9: 57: 00$ & 22.10 & 15.70 & 64 \\
\hline $9: 58: 00$ & 22.00 & 15.60 & 64 \\
\hline $9: 59: 00$ & 22.00 & 15.70 & 64 \\
\hline $10: 00: 00$ & 22.10 & 15.70 & 64 \\
\hline $10: 01: 00$ & 22.00 & 15.70 & 64 \\
\hline$\ldots$ & $\ldots$ & $\ldots$ & $\ldots$ \\
\hline $15: 41: 00$ & 22.50 & 7.00 & 61 \\
\hline $15: 42: 00$ & 21.70 & 18.00 & 61 \\
\hline $15: 43: 00$ & 21.70 & 18.00 & 61 \\
\hline $15: 44: 00$ & 21.70 & 18.00 & 61 \\
\hline $15: 45: 00$ & 21.70 & 17.50 & 61 \\
\hline
\end{tabular}

Fig. 5. Digitizing and analysis form

The process described above is done for each worker separately because of the need to follow her/his activity and movement continuously. The experience of the authors is that otherwise it is very easy to make mistakes.

\subsubsection{Tool testing}

As using this tool requires a lot of work, before entering into massive investment in field experiments and especially in their analysis, the performance of the VBLM was tested on site. The test was conducted during the frame construction of a third floor of an eight story building in Netania. The building elements which were constructed at that time, were reinforced concrete columns and walls and the activity was formwork erection and reinforcement installation, performed conventionally.

The test was conducted by two independent researchers. The first researcher selected 42 locations on the third floor, numbered and marked them on a floor plan. At the next stage he physically moved from one location to the other according to an order of his choice. In each location he raised a label with the number of the location as marked on the floor plan - later the X,Y coordinates of each of these locations were recorded.

The second researcher recorded this operation on video and analyzed it as described in the previous Section (0). The result of this was a table with the X,Y coordinates of all 42 locations. The data of the two tables (that of the first and the one of the second researchers) were compared and the deviations calculated (Table 2). 85.7\% 
of the locations were measured with an accuracy of $\pm 20 \mathrm{~cm}$ and at least $90 \%$ of the locations were measured with an accuracy of $\pm 50 \mathrm{~cm}$. Moreover, the deviation normally occurred in the axis parallel to the erected building element, which means that the deviations in the perpendicular axis to the erected element are almost negligible. Due to the fact that, because of the WE concept, in most cases (apart from the two ends of elements) the perpendicular axis is more important for the geometrical association, it can be determined that the VBLM is a suitable research tool for the purpose of worker location measurement.

Table 2. Accuracy of location measurement with video technology

\begin{tabular}{c|c|c}
\hline Deviation $(\mathrm{cm})$ & Number of locations & Percentage \\
\hline $0-20$ & 36 & $85.7 \%$ \\
\hline $20-40$ & 1 & $2.4 \%$ \\
\hline $40-60$ & 1 & $2.4 \%$ \\
\hline $60-80$ & 2 & $4.8 \%$ \\
\hline $80-100$ & 2 & $4.8 \%$ \\
\hline Total & 42 & $100.0 \%$ \\
\hline
\end{tabular}

\subsubsection{Pilot test}

A pilot test was conducted to check how the measurement technique performs as a research tool. The test was conducted during the frame construction of the ground floor of an eight story building in the same site in Netania where the 4.3.2. Tool testing was conducted. One worker was monitored for 350 minutes, performing column and wall formwork erection for three building elements: protected rooms (PR) \# 1 and 2 and a stair shaft (SSH). The construction method was conventional using wood formwork. The video camera was installed on a nearby building, also under construction by the same company.

The video was analyzed - Fig. 5 shows part of the digitized locations in a DA form. These locations were then fed into the conversion algorithms. The result of this was an association of locations to building elements that the worker worked on. As in Kiryat Yam, here too, the logical association was done once with the regular DR and a second time with the improved ones. The results of the analysis appear in Fig. 6, which shows the three building elements on the horizontal axis and the percent of

$\square$ Mod. LA ㅂ Logical Association (LA) $\square$ Geometrical Association

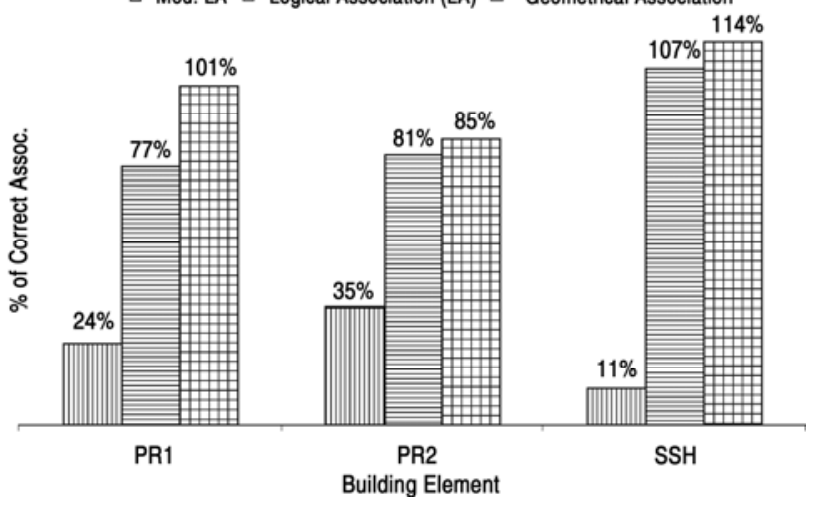

Fig. 6. Analysis results from the pilot study the correct association on the vertical axis. The rate of the geometrical association was between 11-35\%. The logical association stage increased the correct association to 77\% for PR1, 81\% for PR2 and 107\% for SSH. With the improved DR (modified LA) the rate of correct association meaningfully improved for PR1, slightly improved for PR2 and was worse for SSH.

The accuracy level achieved in the pilot test was $\pm 23 \%$ for the standard DR and $\pm 14 \%$ for the improved ones. This is approximately the same accuracy level of the manual location measurement. Hence, at this stage, this technique was deemed suitable.

\section{Conclusions}

Automated measurement and control of labor performance is a challenging area of research because of the following reasons: (i) Labor performance cannot be automatically measured directly. The authors have identified an indirect parameter - the location of the worker as function of time - which can be converted into labor productivity. (ii) The factors affecting the quality, accuracy and integrity of information generated using such an approach, are not known - now that a proper research tool was developed, these factors can be investigated in more depth. (iii) There is a technological difficulty to measure worker location automatically. The authors have indicated directions to solve this problem (Navon and Goldschmidt 2003b). In absence of adequate off-the-shelf technology as a research tool, this paper explored ways to perform this measurement in an objective way.

At first, a manual simulation of location measurement was tested in the field. This attempt yielded several conclusions; the main one is that the selected indirect parameter is suitable for labor performance measurement. On the other hand, it was apparent that this method is not objective enough and it cannot test the entire model. Additionally, the results of the experiments could not be checked retroactively, neither could they be reproduced.

The next step was an attempt to use GPS technology because of its availability off-the-shelf. This technology turned out to be unsuitable especially for building construction. Additionally it introduced other problems such as absence of location readings for meaningful periods of time.

Another off-the-shelf technology - video photography - was found suitable and useful as a research tool for location measurement. This solution is not ideal because it is labor intensive, but for research purposes it is acceptable. This will enable the authors to continue the research and try to answer some of the research questions regarding the factors that affect automated labor performance measurement. After these questions are answered, a dedicated technology could be developed to make the automated measurement more practically feasible.

A few years ago we proposed a method for location measurement using RFID technology (Navon and Goldschmidt 2003 b). Recently we have been working on a different approach to automated labor control using RFID. In this approach the location measurement and the first stage of geometrical association are skipped. The RFID reader reads tags pre-installed in the building elements and 
the algorithm associates the time of measurement to building elements. Here, too, the association may be to one, or more elements, or none at all. We are currently conducting simulated experiments, which will be reported separately.

\section{References}

Akinci, B.; Fischer, M., Kuntz, J. and Levit, R. 2002. Representing work spaces generically in construction method models, Journal of Construction Engineering and Management - ASCE 128(4): 296- 305. doi:10.1061/(ASCE)0733-9364(2002)128:4(296)

Caterpillar. 2009. CAESultra - Computer Aided Earthmoving System.

Chul, K. S. and Liang, Y. L. 2008. Cost information model for managing multiple projects, Journal of Construction Engineering and Management -ASCE 133(12): 966-974.

COMPASS-IP 2009. Information Systems.

Echeverry, D. and Beltran, A. 1997. Bar-code control of construction field personnel and construction materials, in 4th Congress on Computing in Civil Engineering, Philadelphia, Pennsylvania (USA).

Fayek, A.; AbouRizk, S. and Boyd, B. 1998. Implementation of automated site data collection with a medium-sized contractor, in Proc of 1998 International Computing Congress on Computing in Civil Engineering, October 18-21, 1998, Boston, USA, 454-457.

Goldschmidt, E. and Navon, R. 1996. Automated real-time manpower productivity control, in The Eighth International Symposium on Organization \& Management of Construction, Glasgow, UK.

Hegazy, T. and Ersahin, T. 2001. Simplified spreadsheet solutions: I: Subcontractor information system, Journal of Construction Engineering and Management - ASCE 127(6): 461-468. doi:10.1061/(ASCE)0733-9364(2001)127:6(461)

Jang, W.-S. and Skibniewski, M. J. 2009. Embedded system for construction asset tracking combining radio and ultrasound signals, Journal of Computing in Civil Engineering-ASCE 23(4): 221-229. doi:10.1061/(ASCE)0887-3801(2009)23:4(221)

Jaselskis, E. J. and El-Misalami, T. 2003. Implementing radio frequency identification in the construction process, Journal of Construction Engineering and Management ASCE 129(6): 680-688.

doi:10.1061/(ASCE)0733-9364(2003)129:6(680)
JohnDeere. 2009. JDLink Machine Monitoring System.

Navon, R. and Goldschmidt, E. 2003a. Can labor inputs be measured and controlled automatically? Journal of Construction Engineering and Management - ASCE 129(4): 437445. doi:10.1061/(ASCE)0733-9364(2003)129:4(437)

Navon, R. and Goldschmidt, E. 2003b. Monitoring labor inputs: automated-data-collection model and enabling technologies, Automation in Construction 12(2): 185-199. doi:10.1016/S0926-5805(02)00043-2

Navon, R.; Goldschmidt, E. and Shpatnisky, Y. 2004. A concept proving prototype of automated earthmoving control, Automation in Construction 13(2): 225-239. doi:10.1016/j.autcon.2003.08.002

Navon, R. and Haskaya, I. 2007. Is detailed progress monitoring possible without designated manual data collection? Construction Management and Economics 24(12): 12251229. doi:10.1080/01446190600999097

Oglesby, C.; Parker, H. and Howell, G. A. 1989. Productivity Improvement in Construction. NY, McGraw-Hill.

Oh, S.W.; Chang, H. J.; Kim, Y. S.; Lee, J. B. and Kim, H. S. 2004. An application of PDA and barcode technology for the improvement of information management in construction projects, in Proc of 21st International Symposium on Automation and Robotics in Construction, September 2125, 2004, Jeju, Korea, 518-524.

Peyret, F. and Tasky, R. 2004. A traceability system between plant and work site for asphalt pavements, ComputerAided Civil and Infrastructure Engineering 19(1): 54-63. doi:10.1111/j.1467-8667.2004.00337.x

Riley, D. R. and Sanvido, V. E. 1995. Patterns of constructionspace use in multistory buildings, Journal of Construction Engineering and Management - ASCE 121(4): 464-473. doi:10.1061/(ASCE)0733-9364(1995)121:4(464)

Taylor, D. and Tometich, T. 2003. GPS in the real world of site development, in 3rd Biennial World Conference on Automated Data Collection in Construction (CD-Rom), Las Vegas, USA, University of East Carolina.

Trimble. 2009. SiteVision GPS System.

Winch, G. and Carr, B. 2001. Benchmarking on-site productivity in France and the UK: a CALIBRE approach, Construction Management and Economics 19: 577-590. doi:10.1080/01446190110062465

\section{DARBININKŲ IŠSIDĖSTYMO İVETINIMO METODŲ KAIP PRIEMONĖS AUTOMATIZUOTAI DARBO JËGOS KONTROLEI TYRIMAS}

\section{R. Navon, E. Goldschmidt}

$\mathrm{S}$ a n t r a u k a

Automatizuotas darbų atlikimo įvertinimas yra aktuali tyrimų sritis. Šioje srityje nèra atlikta daug tyrimų dèl jos sudètingumo ir tinkamų tyrimo priemonių stokos. Iૃvertinimui automatizuoti autoriai taikè netiesioginių rodiklių būdą. Šiame tyrime darbininko buvimo vieta matuojama kaip laiko funkcija ir naudojant specialius algoritmus šie duomenys konvertuojami i darbo ívesties duomenis, t. y. darbo našumą. Šio pobūdžio tyrimams reikia patikimo metodo ar priemonės darbininkų buvimo vietai nustatyti. Tačiau tokios priemonės nèra. Šiame tyrime nagrinejjami trys vietos nustatymo metodai kaip automatizuotos darbo jègos kontrolès priemonès: 1) buvimo vietos nustatymo modeliavimas rankiniu būdu; 2) GPS; 3) fotografavimas. Pirmieji du metodai pasirodè subjektyvūs, netikslūs ir nepatikimi. Nustatyta, kad trečiasis metodas tinkamas atliekamo tyrimo tikslui. Taikomas klasikinis chronometravimo būdas kartu su vaizdo įrašymo metodika, parengta šio tyrimo metu.

Reikšminiai žodžiai: automatizacija, kontrolès metodai, duomenų rinkimas, tyrimo priemonès.

Ronie NAVON. Associate Professor, Head, Construction Management \& Economics, National Building Research Institute (NBRI), Faculty of Civil \& Environmental Engineering, Technion City, 32000 Haifa, Israel.

Eytan GOLDSCHMIDT. Ph.D., Faculty of Engineering, Department of Civil Engineering, Ariel University Center of Samaria, Israel. 